Bangladesh J. Bot. 42(2): 265-272, 2013 (December)

\title{
INCIDENCE AND BIOLOGY OF CORYNESPORA CASSIICOLA (BERK. \& CURT.) WEI. DISEASE OF OKRA IN BANGLADESH
}

\author{
Fakhruddin Ali Ahmed*, Nazmul Alam and Abul Khair \\ Department of Botany, Jahangirnagar University, Savar, Dhaka-1342, Bangladesh
}

Key words: Incidence, Biology, Corynespora cassiicola, Disease, Okra

\begin{abstract}
Eight commercial okra cultivars were evaluated to determine the magnitude of incidence of Corynespora cassiicola (Berk. \& Curt.) Wei. Maximum and significant incidence of C. cassiicola was 14.86 in the cultivar BARI 1. In rest of the cultivars, the occurrence of this fungus was very poor to nil. Corynespora cassiicola appeared to be a minor pathogen for okra. Effects of temperature, $\mathrm{pH}$ and culture media on growth and sporulation of the fungus were investigated. Potato dextrose agar medium was found to be the most suitable for optimum growth and sporulation of this fungus at $\mathrm{pH} 7$ and $25^{\circ} \mathrm{C}$. The conidial length significantly varied with the changes of $\mathrm{pH}$. The correlation between $\mathrm{pH}$ and conidial length was found negative and highly significant.
\end{abstract}

\section{Introduction}

Okra (Abelmoschus esculentus (L.) Moench) is a popular and important vegetable crop grown mainly for its tender green fruits in Bangladesh, India and Pakistan. The green fruits are rich in vitamin $\mathrm{A}$ and $\mathrm{C}$ and minerals like $\mathrm{Ca}, \mathrm{Mg}$ and Fe. Okra seeds are also good sources of protein and vegetable oil (Yadav and Dhankhar 2001). In Bangladesh, this crop is grown during March to October and suffers from a number of viral and fungal diseases (Ali et al. 2000, Fakir 1976). Fernandes et al. (1990) carried out a preliminary study on health status of okra seeds, collected from different municipalities of Rio de Jenerio state, Brazil and isolated 15 species of pathogenic fungi. Corynespora cassiicola (Berk \& Curt.) Wei., was reported for the first time in 1945 as Helminthosporium vignae Olive and designated as a pathogen of cowpea (Vigna sinensis (L.) Endl. and soybean (Glycine max (L.) Merr.) (Olive et al. 1945). This fungus has been reported as a pathogen for target spot, leaf spot and leaf blight diseases of a number of dicotyledonous plants including okra with a varied degree of virulence depending on the host species throughout the world (Wei 1950, Castro 1979). Fakir (1977), Rahman (1988) and Shamsi and Naher (2010) reported C. cassiicola diseases in Corchorus capsularis L., Hevea brasiliensis (Willd. ex A. Juss.) Müll. Arg. and Vigna sinensis L. respectively from Bangladesh.

In okra, C. cassiicola was first reported as a seed borne pathogen by Fakir (1976) while Ahmed and Khair (2008) reported this pathogen responsible for stem necrosis. However, the incidence and biology of $C$. cassiicola causing diseases in okra has not yet been reported. Therefore, the present work was undertaken to investigate the disease incidence of C. cassiicola in commercial cultivars of okra as well as to study the biology of the fungus.

\section{Materials and Methods}

Seven okra cultivars, namely BARI 1, Parvanikranti, Chittagong iron, Parash 2, Sabuj bangla, Pan and Sirajuddoula were collected from commercial seed stores of Siddique bazaar, Dhaka, Bangladesh. In addition, an introduced cultivar, 'red okra', brought from China was acclimatized in the field condition of Bangladesh and included in the present study. Survey on disease incidence of C. cassiicola was carried out for three consecutive year (2005 to 2007) in the

*Author for correspondence: <faahmed_ju@yahoo.com> 
experimental plots at the Botanical garden of Jahangirnagar University following completely randomized block design (RBD). Diseased plants were categorized on the basis of the percentage of diseased surface area (including leaf and stem) according to the scale and formula of Singh (1984).

In order to test the pathogenicity, the causal fungus was first isolated from the transitional zone of healthy and diseased tissue on $2 \%$ potato dextrose agar (PDA) medium following Dhingra and Sinclair (1985) and was identified on the basis of microscopic characters and cultural behaviour (Ellis 1971, Subramanian 1971). Stems and fruits of okra, grown under restricted condition, were surface sterilized with $0.5 \% \mathrm{NaOCl}$ then washed with sterilized distilled water. Pathogenicity tests were performed by pricking surfaces of stems and fruits of okra, up to a depth of $0.5 \mathrm{~mm}$, of each of 25 test plants, on which a mycelium plug $(2.0 \mathrm{~mm}$ in diameter) cut from the edge of a 7-day-old monosporic fungal cultures was placed. In control plants a sterile PDA plug was placed on each wound. To conduct leaf-pathogenicity test, a conidial suspension (ca. $2 \times 10^{-4}$ conidia/ml) was prepared in sterile water by harvesting conidia from 10-day-old fungal cultures and the suspension was sprayed on to the 25 leaves of three healthy plants. Inoculated plants were kept in humid condition by repeated spraying with sterile water in a polyethylene chamber for the first $48 \mathrm{hrs}$ and thereafter placed in controlled environment. Symptoms similar to those shown by naturally infected plants developed on the wounded stems, fruits and leaves 7 days after inoculation. C. cassiicola was re-isolated successfully from the inoculated plants, confirming Koch's postulates. Control plants remained symptomless.

Potato dextrose agar, corn-meal agar, Czapek's Dox agar, malt extract agar, Richards' medium, Waksman's medium and okra leaf extract agar were tested to select the appropriate growth medium for the fungi. Besides, the test fungus was grown on PDA with varying $\mathrm{pH}$ and temperature to assess its biological features. PDA medium was adjusted to different $\mathrm{pH}$ levels viz., 4.0, 5.0, 6.0, 7.0, 8.0, 9.0 and 10.0 with $1 \mathrm{~N} \mathrm{NaOH}$ or $1 \mathrm{~N} \mathrm{HCl}$ by using $\mathrm{pH}$ meter.

\section{Results and Discussion}

Okra plants infected with C. cassiicola showed necrotic leaf spot, stem necrosis and fruit rot. Infected leaves consist of lesions with pale yellow to brownish centers having irregular outer rings of gray to dark brown margin (Fig. 1A). Sometime the centre of the lesion was found cracked. The symptom on the infected stem first appeared as a number of very minute, dark, water soaked circular spots that coalesced later and formed a large necrotic subcircular to irregular region having dark gray to black coloured lesion (Fig. 1B). Initial symptom appeared on the surface of the fruits, in the form of water-soaked lesions of elliptical to irregular in shape. Later the lesions coalesced and produced larger irregular necrotic areas (Fig. 1C). It was confirmed by Koch's postulates that C. cassiicola was the causal pathogen of the disease symptoms (Fig. 1D, E). Partially affected plants bare fruits, which are few in number and of low quality. Severely affected plant showed wilting and died subsequently. Mukerji and Bhasin (1986) listed the 31 fungal pathogens, which caused okra associated diseases where C. cassiicola was absent in the list.

Seven commercial cultivars of okra along with an acclimatized cultivar 'red okra' were surveyed for three consecutive years to assess the level of incidence of C. cassiicola causing leaf spot, stem necrosis and fruit rot disease. Disease incidence presented in Table 1 is the sum total of disease incidence on leaf, stem and fruits. The disease occurred usually after the maturity (45-50 DAS) of Okra plants. Maximum and significant (at $0.05 \%$ level) disease incidence were 14.86 , 12.86 and 9.51 recorded during the year 2005, 2006 and 2007, respectively in the cultivar BARI 1. In rest of the cultivars the occurrence of this fungus was very poor to nil (Table 1). Disease 
incidence in the particular cultivars did not change much with the change of cultivating year. Therefore, variation in disease incidence could be attributed to the genotypic variation rather than seasonal.
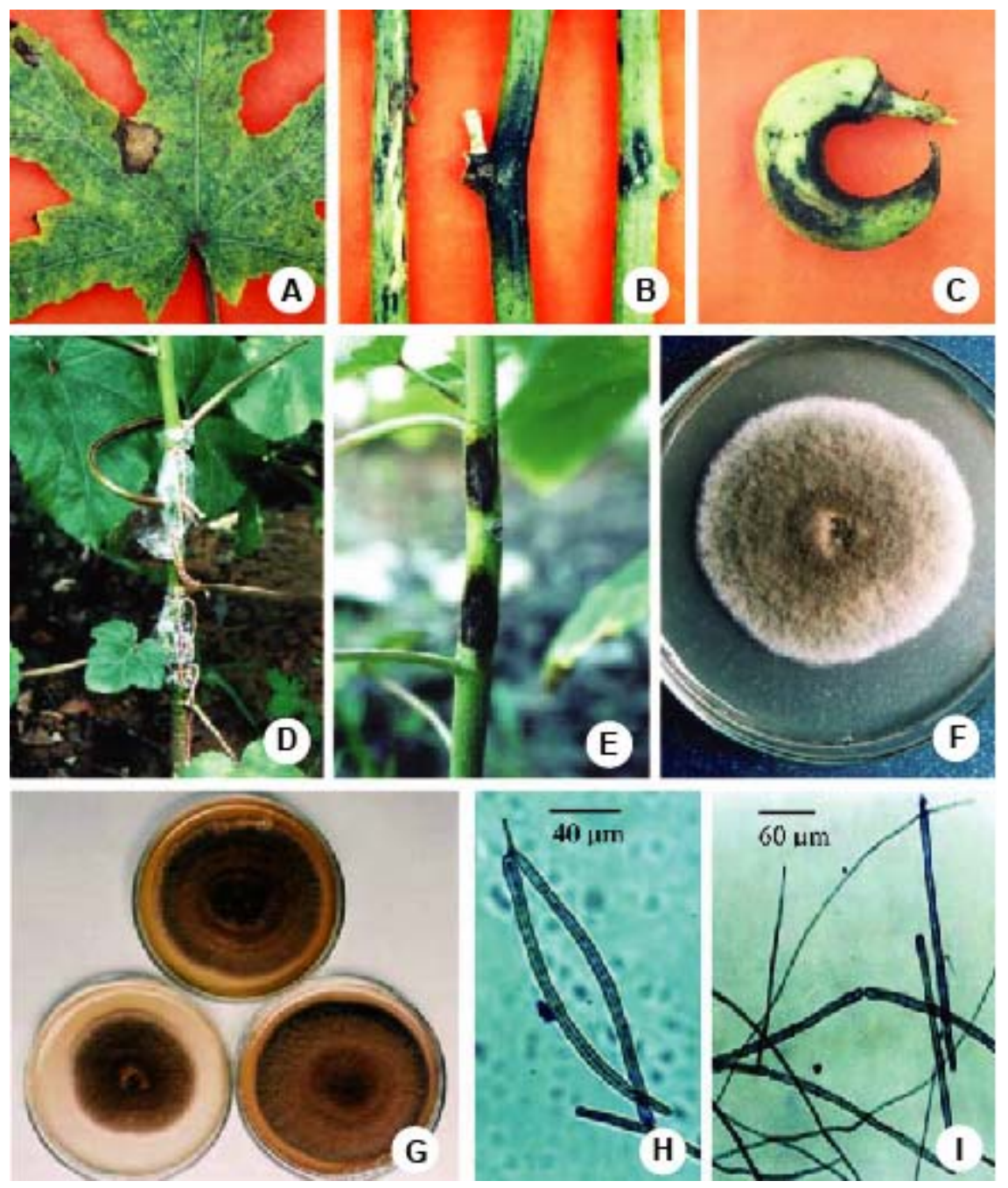

Fig. 1. Corynespora cassiicola disease of okra. A. Leaf spot symptom. B. Different magnitude of stem necrosis and C. Fruit rot symptom produced by C. cassiicola under natural condition.. D \& E. Appearance of stem necrosis symptom after artificial inoculation. F \& G. Typical colony of $C$. cassiicola on PDA medium. H. Characteristic conidial feature $(\times 200)$ and I. Conidial chain with mycelium $(\times 100)$ of $C$. cassiicola viewed under microscope.

Leaves, stems and fruits of eight commercial cultivars of okra were inoculated with $C$. cassiicola to test the magnitude of pathogenicity on each of the plant part (Fig. 2). In each of the three trial, 25 inoculation sites made separately in leaves, stems and fruits under controlled condition where relative humidity was $97 \pm 2 \%$. Significant and maximum number of disease symptoms on leaves, stems and fruits were produced in the cultivar BARI 1 , followed by 
Parvanikranti, Sirajuddoula and Pan cultivars respectively. Sabuj bangla cultivar did not show any disease symptom whereas cultivars Parash 2 and Red okra showed very little response to this pathogen. The diminutive occurrence of $C$. cassiicola in eight cultivars indicates it as a minor pathogen of okra.

Table 1. Incidence of Corynespora cassiicola recorded as per cent disease index (PDI) in eight cultivars of okra during summer 2005 to 2007.

\begin{tabular}{llll}
\hline \multirow{2}{*}{ Cultivars } & \multicolumn{3}{c}{ Cultivation year } \\
\cline { 2 - 4 } & 2005 & 2006 & 2007 \\
\hline Red okra & $0.0 \mathrm{c}$ & $0.0 \mathrm{c}$ & $0.0 \mathrm{c}$ \\
BARI 1 & $14.86 \mathrm{a}$ & $12.86 \mathrm{a}$ & $9.51 \mathrm{a}$ \\
Parvanikranti & $3.33 \mathrm{~b}$ & $0.72 \mathrm{bc}$ & $2.33 \mathrm{~b}$ \\
Chittagong iron & $1.07 \mathrm{~b}$ & $0.0 \mathrm{a}$ & $1.33 \mathrm{~b}$ \\
Parash 2 & $0.72 \mathrm{bc}$ & $0.24 \mathrm{~b}$ & $0.0 \mathrm{c}$ \\
Sabuj bangla & $0.0 \mathrm{c}$ & $0.0 \mathrm{c}$ & $0.0 \mathrm{c}$ \\
Pan & $1.33 \mathrm{bc}$ & $0.0 \mathrm{c}$ & $0.0 \mathrm{c}$ \\
Sirajuddoula & $1.91 \mathrm{bc}$ & $1.32 \mathrm{bc}$ & $1.76 \mathrm{~b}$ \\
\hline
\end{tabular}

Data are average of five replications. In a column means followed by a common letter are not different significantly at $5 \%$ level by DMRT.

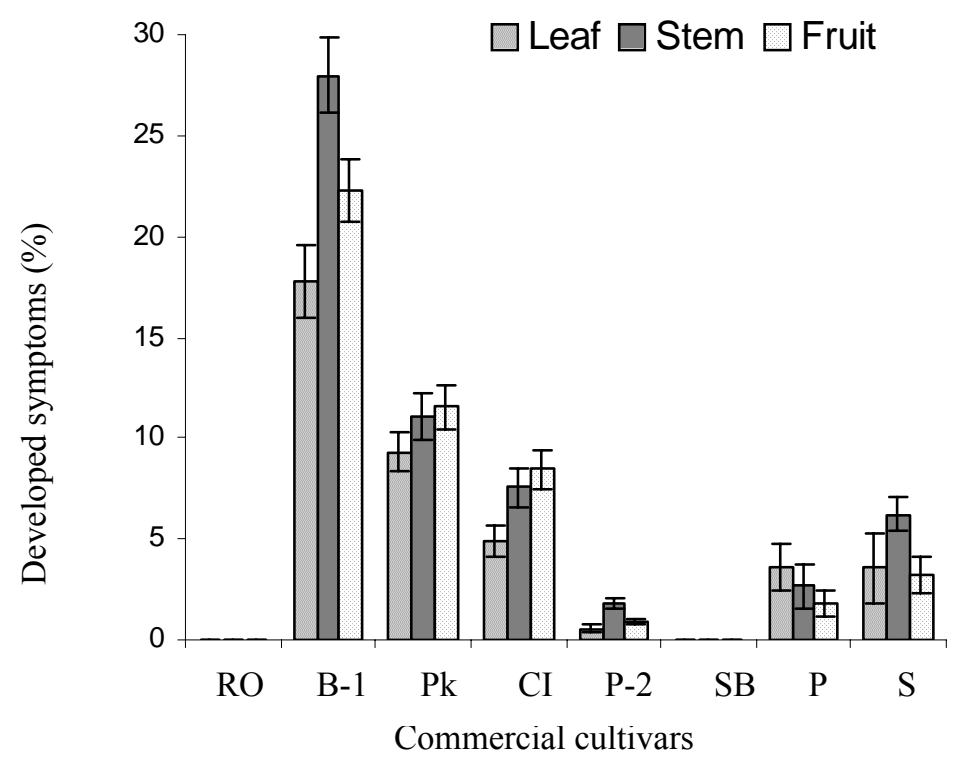

Fig. 2. Percentage of disease symptom $( \pm \mathrm{SE})$ produced in eight cultivars of okra after artificial inoculation under controlled condition. $\mathrm{RO}=$ Red okra, B-1 = BARI-1, Pk $=$ Parvanikranti, $\mathrm{CI}=$ Chittagong Iron, $\mathrm{P}-2=$ Parash-2, $\mathrm{SB}=$ Sabuj bangla, $\mathrm{P}=\mathrm{Pan}$ and $\mathrm{S}=$ Sirajuddoula 
Colony of C. cassiicola on PDA medium appeared as effuse, gray to light olivaceous green at immature stage and turned brown to dark blackish brown at maturity, often hairy or velvety (Fig. $1 F, G)$. Conidia formed solitary or in chains of $2-6$, very variable in shape, obclavate to cylindrical, straight or curved, pale olivaceous brown or brown, smooth, with 4 - 20 pseudosepta and measured $41.2-219.7 \mu$ long and $9.2-21.5 \mu$ wide (Fig. 1H, 1I). The potato dextrose agar (PDA) medium at $25^{\circ} \mathrm{C}$ temperature was found optimum for the growth and sporulation of the test fungus, which greatly corroborates with the findings of Tsay and Kuo (1991). Effect of temperature on spore germination and mycelial growth was determined by growing the fungus on PDA medium at $\mathrm{pH} 7$ with varying temperature. The fungus grew about $7.87 \mathrm{~cm}$ in diameter of colonies at $25^{\circ} \mathrm{C}$ in one week. Whereas, the optimum temperature for spore germination and mycelial growth ranged between 25 and $30^{\circ} \mathrm{C}$, which was statistically significant at $5 \%$ level by DMRT (Table 2).

Table 2. Effect of temperature on spore germination and mycelial growth of Corynespora cassiicola.

\begin{tabular}{ccc}
\hline Temperature $\left({ }^{\circ} \mathrm{C}\right)$ & Spore germination $(\%)^{*}$ & Diameter of colony $(\mathrm{cm})^{* *}$ \\
\hline 10 & $15.5 \mathrm{~d}$ & $2.22 \mathrm{~d}$ \\
15 & $55.8 \mathrm{c}$ & $4.13 \mathrm{c}$ \\
20 & $73.6 \mathrm{~b}$ & $5.66 \mathrm{~b}$ \\
25 & $87.3 \mathrm{a}$ & $7.87 \mathrm{a}$ \\
30 & $94.1 \mathrm{a}$ & $7.61 \mathrm{a}$ \\
35 & $91.6 \mathrm{a}$ & $4.46 \mathrm{c}$ \\
\hline
\end{tabular}

*Inoculum on water agar for $3 \mathrm{hrs}$ and 3 replications for each treatment. ${ }^{* *}$ Growth on PDA for 7 days and 3 replications for each treatment. In a column means followed by the same letter are not different significantly at $5 \%$ level by DMRT.

Vegetative growth of $C$. cassiicola was investigated using some common culture media at $\mathrm{pH}$ 7 and $25^{\circ} \mathrm{C}$ and has been presented in Table 3. After a week of incubation, maximum mycelial growth was recorded on PDA $(8.27 \mathrm{~cm})$ followed by okra leaf extract agar $(7.44 \mathrm{~cm})$ and Czapex dox's agar $(7.03 \mathrm{~cm})$ respectively. Minimum mycelial growth was recorded in corn-meal agar $(1.08 \mathrm{~cm})$ followed by Waksman's medium $(2.23 \mathrm{~cm})$. Richard's medium and malt extract agar

Table 3. Effect of different culture media on growth of the Corynespora cassiicola.

\begin{tabular}{llllllll}
\hline \multirow{2}{*}{ Culture medium } & \multicolumn{7}{c}{ Mycelial growth $(\mathrm{cm})$ at constant temperature and $\mathrm{pH}$} \\
\cline { 2 - 7 } & Day 1 & Day 2 & Day 3 & Day 4 & Day 5 & Day 6 & Day 7 \\
\hline Potato dextrose agar & $0.63 \mathrm{a}$ & $1.42 \mathrm{a}$ & $2.68 \mathrm{a}$ & $3.67 \mathrm{a}$ & $5.38 \mathrm{a}$ & $7.71 \mathrm{a}$ & $8.27 \mathrm{a}$ \\
Corn-meal agar & $0.08 \mathrm{c}$ & $0.18 \mathrm{~d}$ & $0.33 \mathrm{~d}$ & $0.48 \mathrm{~d}$ & $0.70 \mathrm{e}$ & $1.00 \mathrm{e}$ & $1.08 \mathrm{f}$ \\
Czapek's Dox agar & $0.54 \mathrm{a}$ & $1.21 \mathrm{~b}$ & $2.28 \mathrm{ab}$ & $3.12 \mathrm{ab}$ & $4.57 \mathrm{~b}$ & $6.55 \mathrm{ab}$ & $7.03 \mathrm{~b}$ \\
Malt extract agar & $0.23 \mathrm{~b}$ & $0.53 \mathrm{c}$ & $0.99 \mathrm{c}$ & $1.36 \mathrm{~cd}$ & $1.99 \mathrm{~d}$ & $2.85 \mathrm{~d}$ & $3.06 \mathrm{~d}$ \\
Richards' medium & $0.38 \mathrm{ab}$ & $0.85 \mathrm{bc}$ & $1.61 \mathrm{~b}$ & $2.20 \mathrm{c}$ & $3.23 \mathrm{c}$ & $4.63 \mathrm{e}$ & $4.96 \mathrm{c}$ \\
Waksman's medium & $0.17 \mathrm{bc}$ & $0.38 \mathrm{~d}$ & $0.72 \mathrm{c}$ & $0.99 \mathrm{~cd}$ & $1.45 \mathrm{~d}$ & $2.08 \mathrm{~d}$ & $2.23 \mathrm{c}$ \\
Okra leaf extract agar & $0.57 \mathrm{a}$ & $1.28 \mathrm{~b}$ & $2.41 \mathrm{ab}$ & $3.30 \mathrm{ab}$ & $4.84 \mathrm{~b}$ & $6.94 \mathrm{ab}$ & $7.44 \mathrm{~b}$ \\
\hline
\end{tabular}

Note: Data are averages of three replications. In a column means followed by the same letter are not different significantly at $5 \%$ level by DMRT.

media were found moderately suitable for C. cassiicola. In contrast, Oluma and Amuta (1999) reported faster growth of this fungus on malt-extract agar (MEA) media and slowest growth on potato-dextrose agar (PDA) supplemented with thiamine. However, Fernando et al. (2012) reported that PDA was one of the best media for growth and sporulation of C. cassiicola. 
To determine the optimum $\mathrm{pH}$, the fungus was grown on $\mathrm{PDA}$ at $25^{\circ} \mathrm{C}$ and varying $\mathrm{pH}(4-10)$ for seven days. Initially, the mycelial growth of the fungus in different $\mathrm{pH}$ did not vary much but at maturity $\mathrm{pH}$ values were found to set profound effect on growth. From day 3 to 5 , the fungus showed consistent mycelial growth from $\mathrm{pH} 6$ to 8 but on $6^{\text {th }}$ and $7^{\text {th }}$ day, statistically significant maximum growth was observed at $\mathrm{pH} 7$ and 8 , followed by $\mathrm{pH} 5,6$ and 9 respectively (Table 4). The optimum $\mathrm{pH}$ for the growth and sporulation ranged between 5 and 8 , which corroborates with the findings of Chunxia et al. (2010) as they reported $4-8 \mathrm{pH}$ was optimum for growth of this fungus.

Table 4. Effect of pH on the growth of Corynespora cassiicola.

\begin{tabular}{clllllll}
\hline \multirow{2}{*}{$\mathrm{pH}$ of PDA medium } & \multicolumn{7}{c}{ Mycelial growth $(\mathrm{cm})$ at $25^{\circ} \mathrm{C}$} \\
\cline { 2 - 7 } & Day 1 & Day 2 & Day 3 & Day 4 & Day 5 & Day 6 & Day 7 \\
\hline 4 & $0.33 \mathrm{~cd}$ & $0.83 \mathrm{~b}$ & $2.07 \mathrm{~b}$ & $2.67 \mathrm{~d}$ & $3.33 \mathrm{c}$ & $3.62 \mathrm{~d}$ & $4.60 \mathrm{~d}$ \\
5 & $0.45 \mathrm{bc}$ & $1.01 \mathrm{ab}$ & $2.56 \mathrm{a}$ & $3.33 \mathrm{c}$ & $4.37 \mathrm{~b}$ & $5.63 \mathrm{~b}$ & $6.65 \mathrm{~b}$ \\
6 & $0.62 \mathrm{a}$ & $1.22 \mathrm{a}$ & $2.87 \mathrm{a}$ & $3.92 \mathrm{ab}$ & $5.03 \mathrm{a}$ & $5.70 \mathrm{~b}$ & $6.87 \mathrm{~b}$ \\
7 & $0.55 \mathrm{ab}$ & $1.13 \mathrm{ab}$ & $2.61 \mathrm{a}$ & $3.87 \mathrm{ab}$ & $4.94 \mathrm{a}$ & $6.03 \mathrm{a}$ & $7.49 \mathrm{a}$ \\
8 & $0.41 \mathrm{c}$ & $0.93 \mathrm{~b}$ & $2.73 \mathrm{a}$ & $4.03 \mathrm{ab}$ & $5.14 \mathrm{a}$ & $5.91 \mathrm{a}$ & $7.36 \mathrm{a}$ \\
9 & $0.32 \mathrm{~cd}$ & $0.8 \mathrm{bc}$ & $2.62 \mathrm{a}$ & $3.73 \mathrm{bc}$ & $4.81 \mathrm{a}$ & $5.35 \mathrm{bc}$ & $6.12 \mathrm{bc}$ \\
10 & $0.21 \mathrm{~d}$ & $0.53 \mathrm{c}$ & $2.26 \mathrm{~b}$ & $4.33 \mathrm{a}$ & $5.13 \mathrm{a}$ & $5.15 \mathrm{c}$ & $5.51 \mathrm{c}$ \\
\hline
\end{tabular}

*Mean of three replications. In a column means followed by a common letter are not different significantly at the $5 \%$ level of significance by DMRT.

$\mathrm{pH}$ of the medium and corresponding frequency of average spore length have been presented in Table 5. The maximum frequency of spore-length ranged between 25 and $74.9 \mu$ and $\mathrm{pH} 5$ to 10 . At $\mathrm{pH} 4$, most of the spore lengths were between 75 and $99.9 \mu$. Maximum spore length ranged between 150 and $174.9 \mu$, observed at $\mathrm{pH} 4$ to 6 . Though spores with minimum length $(1-24.9 \mu)$ were common in different $\mathrm{pH}$ but the frequency was relatively higher at $\mathrm{pH} 4$ and 10 (Table 5).

Table 5. Effect of pH on spore length of Corynespora cassiicola.

\begin{tabular}{llllllll}
\hline $\begin{array}{l}\text { Spore length } \\
(\mu \mathrm{m})\end{array}$ & \multicolumn{9}{c}{$\mathrm{pH}$} \\
\cline { 2 - 7 } & 4 & 5 & 6 & 7 & 8 & 9 & 10 \\
\hline $1-24.9$ & $8.33 \mathrm{~b}$ & $3.33 \mathrm{c}$ & $1.33 \mathrm{c}$ & $4.00 \mathrm{c}$ & $1.67 \mathrm{c}$ & $5.00 \mathrm{c}$ & $7.33 \mathrm{~b}$ \\
$25-49.9$ & $13.00 \mathrm{ab}$ & $19.00 \mathrm{a}$ & $25.33 \mathrm{a}$ & $23.67 \mathrm{a}$ & $29.67 \mathrm{a}$ & $24.33 \mathrm{a}$ & $17.67 \mathrm{a}$ \\
$50-74.9$ & $14.67 \mathrm{ab}$ & $15.33 \mathrm{a}$ & $7.00 \mathrm{~b}$ & $14.67 \mathrm{~b}$ & $11.67 \mathrm{~b}$ & $11.67 \mathrm{~b}$ & $18.67 \mathrm{a}$ \\
$75-99.9$ & $18.33 \mathrm{a}$ & $9.67 \mathrm{bc}$ & $9.67 \mathrm{~b}$ & $10.33 \mathrm{~b}$ & $8.00 \mathrm{bc}$ & $7.33 \mathrm{c}$ & $5.00 \mathrm{bc}$ \\
$100-124.9$ & $3.33 \mathrm{c}$ & $6.00 \mathrm{bc}$ & $7.00 \mathrm{~b}$ & $1.33 \mathrm{c}$ & $1.33 \mathrm{c}$ & $3.67 \mathrm{c}$ & $2.67 \mathrm{bc}$ \\
$125-149.9$ & $2.33 \mathrm{c}$ & $3.33 \mathrm{c}$ & $3.00 \mathrm{c}$ & $2.33 \mathrm{c}$ & $1.67 \mathrm{c}$ & $0.00 \mathrm{~d}$ & $0.00 \mathrm{~d}$ \\
$150-174.9$ & $1.33 \mathrm{c}$ & $2.33 \mathrm{c}$ & $2.67 \mathrm{c}$ & $0.00 \mathrm{c}$ & $0.00 \mathrm{c}$ & $0.00 \mathrm{~d}$ & $0.00 \mathrm{~d}$ \\
\hline
\end{tabular}

Frequency of spores expressed as per cent (\%) values. Data are average of three observations. In a column means followed by a common letter are not different significantly at the $5 \%$ level of significance by DMRT.

Karl Pearson's co-efficient of rank correlation between $\mathrm{pH}$ and spore length was -0.297 ; which indicates the spore length decreases with the increase of $\mathrm{pH}$ values. t-test was performed to assess the level of significance. At the $99 \%$ confidence level the calculated value of ' $t$ ' was 3.86 , greater than the tabulated value of $\mathrm{t}_{(\alpha=0.01)}=2.57$. 
The correlation between $\mathrm{pH}$ and spore length was little and negative, but statistically highly significant. Alternately it may be inferred that on PDA medium at $25^{\circ} \mathrm{C}$ temperature, lower $\mathrm{pH}$ values favours increase in spore length of $C$. cassiicola but reduces spore frequency at per unit area. The fungus showed variable conidial length with $\mathrm{pH}$. C. cassiicola is regarded as a very variable species within the genus. A comparison of $C$. cassiicola collected on 20 different host plants from various parts of the world has shown a great variation of conidial size for this species (Onesirosan et al. 1974). Another study, involving the comparison of genetic differences among different isolates of $C$. cassiicola, using PCR-based techniques, has shown that there were no detectable genetic differences among such isolates (Silva et al. 1998). Thus the phenomenon of producing variable conidial length remained unexplained.

\section{References}

Ahmed FA and Khair A 2008. First report of stem necrosis of okra by Corynespora cassiicola in Bangladesh. J. Plant Pathol. 90(1): 148-148.

Ali M, Hossain MZ and Sarker NC 2000. Inheritance of yellow vein mosaic virus (YVMV) tolerance in a cultivar of okra (Abelmoschus esculentus (L.) Moench). Euphytica 111: 205-209.

Castro MAS 1979. Leaf blight caused by Corynespora: a new disease on cucumber (Cucumis sativus) in the Valley of culiacan, Sinaloa, Mexico and its chemical control. Plant Dis. Rep. 63(7): 599-601.

Chunxia Z, Mingxia H and Jiazhi L 2010. Biological characteristics of Corynespora cassiicola causing Corynespora leaf fall disease. Plant Prot. 36(2): 98-101.

Dhingra OD and Sinclair JB 1985. Basic Plant Pathology Methods. CRC Press, Boca Raton, Florida. pp.132-163.

Ellis MB 1971. Dematiaceous Hyphomycetes. CABI Publishing, Wallingford, UK. pp. 373.

Fakir GA 1976. Detection of seed-borne fungi in okra, their role and control. A monograph accepted by the Danish Govt. Inst. Seed Pathology. Copenhagen, Denmark. pp. 22.

Fakir GA 1977. Corynespora cassiicola, a new seed borne pathogen of Jute. Bangladesh. J. Jute Fib. Res. 2: 51-55.

Fernandes MCA, Almeida OC, Cunha R and Robbs CF 1990. Preliminary studies of health testing in Okra seed from different municipalities of Rio de Jenerio. Revista Brasileira de Sementes 12(2): 37-43.

Fernando THPS, Jayasinghe CK, Wijesundera RLC and Siriwardane D 2012. Some factors affecting in vitro production, germination and viability of conidia of Corynespora cassiicola from Hevea brasiliensis. J. Natn. Sci. Foundation Sri Lanka 40(3): 241-249.

Mukerji KG and Bhasin J 1986. Plant Diseases of India. Tata McGraw Hill Publishing, India. pp. 21

Olive LS, Bain DC and Lefebvre CL 1945. A leaf spot of cowpea and soybean caused by an undescribed species of Helminthosporium. Phytopathology 35: 822-831.

Oluma HOA and Amuta EU 1999. Corynespora cassiicola leaf spot of pawpaw (Carica papaya L.) in Nigeria. Mycopathologia 145(1): 23-27.

Onesirosan PT, Arny DC and Durbin RD 1974. Host specificity of Nigerian and North American isolates of Corynespora cassiicola. Phytopathology 64: 1364-1367.

Rahman MA 1988. Diseases of Hevea brasiliensis in Bangladesh. Bano Biggyan Patrika 17(1-2): 73-79.

Shamsi S and Naher N. 2010. Phylloplane mycoflora on Vigna sinensis L. Dhaka Univ. J. Biol. Sci. 19(2): 203-206.

Silva WPK, Deverall BJ and Lyon BR 1998. Molecular, physiological and pathological characterization of Corynespora leaf spot from rubber plantations in Sri Lanka. Plant Pathol. 47: 267-277.

Singh RS 1984. Assessment of disease incidence and loss. In: Introduction to the Principles of Plant Pathology ( $3^{\text {rd }}$ edn.), pp. 328, Oxford and IBH publishing company, New Delhi.

Subramanian CV 1971. Hyphomycetes: An account of Indian species, except Cercospora. Indian Council of Agricultural Research, New Delhi. pp. 375. 
Tsay JG and Kuo CH 1991. The occurrence of corynespora blight of cucumber in Taiwan. Plant Prot. Bull. 33: 227-229.

Wei CT 1950. Notes on Corynespora. Mycol. Papers 34: 1-10.

Yadav SK and Dhankhar BS 2001. Correlation studies between various field paramenters and seed quality traits in okra cv. Varsha uphar. Seed Res. 29: 84-88.

(Manuscript received on 30 May, 2013; revised on 1 September, 2013) 